\title{
Dynamic modeling of a three-stage low-temperature ethanol reformer for fuel cell application
}

\author{
Vanesa M. García $^{a *}$, Eduardo López ${ }^{\mathrm{b}}$, Maria Serra ${ }^{\mathrm{a}}$, Jordi Llorca ${ }^{\mathrm{b}}$ \\ ${ }^{a}$ Institut de Robòtica i Informàtica Industrial (CSIC-UPC). Llorens i Artigas 4-6, 08028 \\ Barcelona, Spain. \\ ${ }^{\mathrm{b}}$ Institut de Tècniques Energètiques. Universitat Politècnica de Catalunya. Diagonal \\ 647, ed. ETSEIB. 08028 Barcelona, Spain.
}

Keywords: Hydrogen production, ethanol steam reforming, low temperature reforming, dynamic simulation

* Corresponding author:

Vanesa M. García

Institut de Robòtica i Informàtica Industrial (CSIC-UPC)

Llorens i Artigas 4-6, 08028 Barcelona, Spain

Tel.: (+34) 934015789

e-mail: vgarcia@iri.upc.edu 


\begin{abstract}
A low-temperature ethanol reformer based on a cobalt catalyst for the production of hydrogen has been designed. The reformer comprises three stages: ethanol dehydrogenation to acetaldehyde and hydrogen over $\mathrm{SnO}_{2}$ followed by acetaldehyde steam reforming over $\mathrm{Co}(\mathrm{Fe}) / \mathrm{ZnO}$ catalyst and water gas shift reaction. Kinetic data has been obtained under different experimental conditions and a dynamic model has been developed for a tubular reformer loaded with catalytic monoliths for the production of the hydrogen required to feed a $1 \mathrm{~kW}$ PEMFC.
\end{abstract}

\title{
1. Introduction
}

Fuel cells are attractive power sources largely because they can achieve efficiencies much greater than conventional engines. However, among the most daunting challenges limiting the implementation of fuel cells is the development of a sustainable source of hydrogen. Ethanol is a promising source of hydrogen as it is a renewable source when obtained from biomass, and hence, catalytic steam reforming of ethanol to produce hydrogen for fuel cells is acquiring increasing interest (equation 1). The reaction has been extensively studied over catalysts based on $\mathrm{Ni}, \mathrm{Ni} / \mathrm{Cu}, \mathrm{Co}$, and noble metals $(\mathrm{Pd}$, $\mathrm{Pt}, \mathrm{Rh}$ and $\mathrm{Ru})[1,2]$. The reaction is highly endothermic $\left(\Delta \mathrm{H}_{298}^{0}=347.4 \mathrm{~kJ} \mathrm{~mol}{ }^{-1}\right)$, which accounts for the requirement of reforming temperatures usually above $873 \mathrm{~K}$. At such high temperatures ethanol is mainly reformed into a mixture of $\mathrm{H}_{2}$ and $\mathrm{CO}$ (equation 2), and it is necessary to pass the reformate through a water gas shift reactor in order to generate further hydrogen and eliminate $\mathrm{CO}$ (equation 3), which is a strong 
fuel cell poison. However, cobalt-based catalysts are particularly effective for ethanol steam reforming at lower temperature, 623-673 K [3-6], where the water gas shift reaction is also operative. For this reason, increasing attention is being focused on developing low-temperature catalytic processes with cobalt catalysts.

$$
\begin{aligned}
& \mathrm{C}_{2} \mathrm{H}_{5} \mathrm{OH}+3 \mathrm{H}_{2} \mathrm{O} \rightarrow 6 \mathrm{H}_{2}+2 \mathrm{CO}_{2} \\
& \mathrm{C}_{2} \mathrm{H}_{5} \mathrm{OH}+\mathrm{H}_{2} \mathrm{O} \rightarrow 4 \mathrm{H}_{2}+2 \mathrm{CO} \\
& \mathrm{CO}+\mathrm{H}_{2} \mathrm{O} \rightarrow \mathrm{CO}_{2}+\mathrm{H}_{2}
\end{aligned}
$$

Among different supported cobalt catalysts already tested for low-temperature ethanol steam reforming, the best performance in terms of hydrogen generation, $\mathrm{CO}_{2} / \mathrm{CO}$ ratio, and long-term stability is $\mathrm{ZnO}$-supported cobalt [3]. At $673 \mathrm{~K}, 5.3-5.4 \mathrm{~mol} \mathrm{H}_{2}$ per mol of reacted ethanol is obtained and almost no $\mathrm{CO}$ is present in the reformate when a bioethanol-like mixture $\left(\mathrm{C}_{2} \mathrm{H}_{5} \mathrm{OH}: \mathrm{H}_{2} \mathrm{O} \sim 13\right.$ molar $)$ is reacted at $5000 \mathrm{~h}^{-1}$ [4]. The main undesired product obtained over $\mathrm{Co} / \mathrm{ZnO}$ is methane $(<3 \%$ on a dry basis). Methane may be formed during ethanol steam reforming by ethanol decomposition (equation 4) or methanation of $\mathrm{CO}$ or $\mathrm{CO}_{2}$ (equation 5).

$$
\begin{aligned}
& \mathrm{C}_{2} \mathrm{H}_{5} \mathrm{OH} \rightarrow \mathrm{H}_{2}+\mathrm{CH}_{4}+\mathrm{CO} \\
& \mathrm{CO}_{n}+(2+n) \mathrm{H}_{2} \rightarrow \mathrm{CH}_{4}+n \mathrm{H}_{2} \mathrm{O}
\end{aligned}
$$

Methanation is a very costly side reaction for the production of hydrogen because it consumes between 3 and 4 mol of hydrogen for each mol of methane formed. In addition, the reaction is thermodynamically favored at low temperature. Following a survey addressed to improve the catalytic performance of the $\mathrm{Co} / \mathrm{ZnO}$ system for real 
ethanol steam reforming application, it has been recently reported that the addition of iron has a positive effect in decreasing methane formation [7]. Under the same experimental conditions tested for $\mathrm{Co} / \mathrm{ZnO}$, a $\mathrm{Co}(\mathrm{Fe}) / \mathrm{ZnO}$ catalyst with a molar ratio of $\mathrm{Co}: \mathrm{Fe} \sim 10: 1$ yields up to 30 times less methane. The enrichment in iron that occurs on the surface of cobalt particles in $\mathrm{Co}(\mathrm{Fe}) / \mathrm{ZnO}$ as determined by $\mathrm{X}$-ray photoelectron spectroscopy [7] is expected to modify the surface of cobalt particles and destroy methanation sites with respect to pure cobalt particles.

Another important issue of ethanol reforming is catalyst deactivation. Major deactivation by coking at high temperature $(>873 \mathrm{~K})$ has been reported to be severe over several catalysts [8]. The dehydration of ethanol to ethylene, catalyzed by acid sites on the support [9], is responsible for the formation of polyethylene on the catalyst surface, which in turn is converted to poorly-organized graphitic carbon, or even nanotubes [10]. Deactivation by carbon deposition over $\mathrm{Co} / \mathrm{ZnO}$ during ethanol steam reforming is strongly temperature-dependent, and only above $723 \mathrm{~K}$ it becomes severe [3]. However, the addition of $\mathrm{Na}^{+}$promoter in the preparation of $\mathrm{Co} / \mathrm{ZnO}$ improves the stability of the catalyst by suppressing acid sites responsible for carbon deposition [11]. Therefore, $\mathrm{ZnO}$-supported cobalt doped with iron and $\mathrm{Na}^{+}$appears to be an effective, stable, and low-cost catalyst for generating hydrogen for fuel cell application through ethanol steam reforming at low temperature.

A critical point encountered when ethanol steam reforming is carried out over cobaltbased catalysts (and probably over other supported metals as well) is that the active site for the reforming reaction involves cobalt in a metallic state, but metallic cobalt is formed on the catalyst surface only when the production of hydrogen has started 
because, initially, the reactants (ethanol and excess water) oxidize the surface of cobalt particles. This has been demonstrated to occur by detailed characterization studies carried out with in situ infrared spectroscopy [12] and in situ magnetic measurements under real operation conditions [13]. The answer to this apparent contradiction comes from mechanistic studies. The first step of the low-temperature ethanol steam reforming pathway over cobalt is ethanol dehydrogenation over cobalt oxide to yield equal amounts of acetaldehyde and hydrogen (equation 6) [14]. Then, the hydrogen produced in this first step reduces cobalt oxide into metallic cobalt and the second step of the reaction occurs, which is the reforming of acetaldehyde with steam over metallic cobalt [14] (Figure 1). 
The need for a reducing atmosphere for the reforming step of the process makes ethanol steam reforming over cobalt highly dependent on reaction conditions. One possibility for maintaining a reducing atmosphere over the cobalt catalyst and overcome the problem could be by separating the two steps of the overall reaction in two catalytic beds and by using two different catalysts: a first step where ethanol dehydrogenates into acetaldehyde and hydrogen over an appropriate catalyst, followed by the reforming of acetaldehyde over the cobalt catalyst. In this way, the cobalt catalyst would be always under hydrogen atmosphere resulting from ethanol dehydrogenation in the first step, and not influenced by variations in the redox environment given by reactants and products during the reforming step. An additional advantage of this method is that it allows maintaining a different temperature regime for each step of the reaction, which may result in a better thermal optimization of the process, which in turn may benefit the final selectivity of the process towards the reforming products, $\mathrm{H}_{2}$ and $\mathrm{CO}_{2}$. Finally, to lower down the $\mathrm{CO}$ content, a water gas shift module operating at a lower temperature can be introduced as third step. In Figure 2, a schematic draw of the three stages reforming process is shown. 
In this work we address the dynamic modeling of such a three-module device for feeding hydrogen to a fuel cell. We have chosen three specific catalysts for each of the three steps of the overall reaction. For ethanol dehydrogenation we use nanocrystalline $\mathrm{SnO}_{2}$, for the reforming step we use $\mathrm{Co}(\mathrm{Fe}) / \mathrm{ZnO}$ doped with $\mathrm{Na}^{+}$, and for the final water gas shift step we use a commercial catalyst based on $\mathrm{Fe}_{2} \mathrm{O}_{3^{-}}$ $\mathrm{Cr}_{2} \mathrm{O}_{3}$. We first carry out detailed kinetic experiments over well-defined samples for the first two stages of the process and we present fitted parameters for power-law type kinetic expressions to quantify the correspondent reaction rates. A dynamic mathematical model of the three-stage reformer is introduced as a tool for controloriented devices design. Finally, introductory simulation results are presented in order to show the dynamic behavior of the system.

\section{Experimental section}

\subsection{Catalysts preparation}

$\mathrm{SnO}_{2}$ was prepared by precipitation by the addition of ammonia to a $\mathrm{SnCl}_{4}$ solution. The solid was aged for $2 \mathrm{~h}$, dried at $303 \mathrm{~K}$, and rinsed with distilled water repeatedly for chloride elimination. The resulting solid was dried at $373 \mathrm{~K}$ and treated at $573 \mathrm{~K}(0.5 \mathrm{~K}$ $\min ^{-1}$ ) for $6 \mathrm{~h}$. $\mathrm{Co}(\mathrm{Fe}) / \mathrm{ZnO}$ catalyst with a cobalt content of $10 \%$ by weight, sodium content of $0.9 \%$ by weight, and Fe content of $1 \%$ by weight was prepared by coprecipitation at $313 \mathrm{~K}$ by the addition of a $\mathrm{Na}_{2} \mathrm{CO}_{3}$ solution to $\mathrm{Zn}\left(\mathrm{NO}_{3}\right)_{2}, \mathrm{Co}\left(\mathrm{NO}_{3}\right)_{2}$, and $\mathrm{Fe}\left(\mathrm{NO}_{3}\right)_{2}$ solutions. After aging at $313 \mathrm{~K}$ for $1.5 \mathrm{~h}$, the suspension was filtered and the 
resulting solid washed with distilled water, dried at $363 \mathrm{~K}$ overnight, treated in air at $673 \mathrm{~K}\left(2 \mathrm{~K} \mathrm{~min}^{-1}\right)$ for $6 \mathrm{~h}$, and reduced under hydrogen at $673 \mathrm{~K}\left(2 \mathrm{~K} \mathrm{~min}^{-1}\right)$ for $6 \mathrm{~h}$.

\subsection{Catalysts characterization}

Chemical composition of catalysts was obtained by optical emission spectroscopy with inductively-coupled plasma (ICP-OES, Perkin-Elmer Optima apparatus). BET surface area was determined using a Micromeritics ASAP 9000 apparatus. X-ray diffraction profiles (XRD) were collected at a step width of 0.02 degrees and by counting $10 \mathrm{~s}$ at each step with a Siemens D-500 instrument equipped with a $\mathrm{Cu}$ target and a graphite monochromator. High resolution transmission electron microscopy (HRTEM) was performed with a JEOL JEM 2010F electron microscope equipped with a field emission gun electron source operated at $200 \mathrm{kV}$ and an Energy Electron Loss Spectrometer (EELS). Photoelectron spectra (XPS) were acquired with a Perkin-Elmer PHI-5500 spectrometer equipped with an Al X-ray exciting source and a hemispherical electron analyzer.

\subsection{Catalytic tests}

All the kinetic experiments were carried out at atmospheric pressure in a tubular reactor placed inside a temperature-controlled heating furnace. Experiments were conducted in the 573-673 K temperature range. An ethanol-steam mixture $\left(\mathrm{C}_{2} \mathrm{H}_{5} \mathrm{OH}: \mathrm{H}_{2} \mathrm{O}=1: 6\right.$, molar basis) or acetaldehyde-steam mixture $\left(\mathrm{C}_{2} \mathrm{H}_{4} \mathrm{O}: \mathrm{H}_{2} \mathrm{O}=1: 6\right.$, molar basis $)$ was mixed with inert carrier gas and contacted with the catalyst inside the reactor. Products were analyzed on-line by gas chromatography and mass spectrometry. The reactor was 
brought to temperature under inert carrier gas flow before reaction. $\mathrm{SnO}_{2}$ was used without any treatment, whereas the $\mathrm{Co}(\mathrm{Fe}) / \mathrm{ZnO}$ catalyst was treated inside the reactor under flowing, diluted $\mathrm{H}_{2}\left(30 \mathrm{~mL} \mathrm{~min}^{-1}\right)$ at $673 \mathrm{~K}$ for $1 \mathrm{~h}$ prior to kinetic experiments. The weight of catalysts samples was varied in the range $0.03-0.1 \mathrm{~g}$. The flow rates of ethanol and acetaldehyde were in the range $0.8-6.4 \mathrm{~mL} \mathrm{~min}^{-1}$, while the total volumetric flow rate at reactor inlet, $\mathrm{Q}$, was varied in the range $50-400 \mathrm{~mL} \mathrm{~min}^{-1}$. Such diluted conditions assured a negligible volume change due to reaction. In addition, the volumetric flow rates were high enough to ensure the absence of external mass transfer limitations. This was confirmed when the conversion at a given temperature was the same even when $\mathrm{Q}$ was increased while keeping the ratio between the weight of catalyst, W, and the molar flow rate of ethanol at reactor inlet constant. Also, no pore diffusion resistance was encountered when varying catalyst particle size.

\section{Catalytic and kinetic results}

\subsection{Ethanol dehydrogenation over $\mathrm{SnO}_{2}$}

The BET surface area of the $\mathrm{SnO}_{2}$ catalyst was $120 \mathrm{~m}^{2} \mathrm{~g}^{-1}$. XRD and HRTEM showed that the catalyst is comprised exclusively by $\mathrm{SnO}_{2}$ particles of about $5 \mathrm{~nm}$. This is well exemplified in Figure 3a, where X-ray diffraction lines are broad and correspond, according to the Scherrer equation, to particles of $4.5 \mathrm{~nm}$. Figure $4 \mathrm{a}$ depicts a representative HRTEM image of this catalyst, showing particles in the range 4-6 nm, and its associated selected-area electron diffraction pattern with rings corresponding to multiple $\mathrm{SnO}_{2}$ crystallites. 
Under the temperature and W/Q conditions tested in this study, ethanol reacts over $\mathrm{SnO}_{2}$ to yield exclusively acetaldehyde and hydrogen according to the reaction:

$$
\mathrm{C}_{2} \mathrm{H}_{5} \mathrm{OH} \rightarrow \mathrm{C}_{2} \mathrm{H}_{4} \mathrm{O}+\mathrm{H}_{2}
$$

In all cases, the yield of hydrogen approximately equals that of acetaldehyde as expected from the reaction stoichiometry $\left(\left[\mathrm{C}_{2} \mathrm{H}_{4} \mathrm{O}\right]:\left[\mathrm{H}_{2}\right]=1: 1\right)$. The order of the reaction was established by variation of the ethanol flow rate at a series of temperatures between 573 and $673 \mathrm{~K}$. For a first-order reaction, the following relation holds true:

$$
x=1-e^{-k W / Q}
$$

where $\mathrm{x}$ is the degree of reactant conversion calculated on a molar basis as:

$$
x=\frac{c_{\text {in }}-c_{\text {out }}}{c_{\text {in }}}
$$

Equation (7) can be rearranged as:

$$
\ln (1-x)=-k(W / Q)
$$

A plot of $\ln (1-\mathrm{x})$ vs. W/Q at various temperatures is shown in Figure 5. As expected, for a given value of $\mathrm{W} / \mathrm{Q}$, the ethanol conversion increases with increasing temperature. It is also evident that the data at each temperature fall on a straight line. Therefore, the dehydrogenation reaction of ethanol is a first-order reaction and, according to equation (9), the slopes of the lines correspond to the specific reaction rate constant at the experimental temperatures. The values of $\mathrm{k}$ at the different temperatures tested along with the $95 \%$ confidence intervals are given in Table 1 . A pre-exponential factor of $7.5 \times 10^{9} \mathrm{~mL} \cdot \mathrm{g}_{\text {cat }}{ }^{-1} \cdot \mathrm{h}^{-1}$ is fitted from the data in Table 1 for an Arrhenius-type expression for the reaction rate constant $(k)$. An Arrhenius plot of the rate constants exhibits good linearity, as depicted in Figure 6. An activation energy of $66 \pm 2 \mathrm{~kJ} \mathrm{~mol}^{-1}$ is obtained. The $\mathrm{SnO}_{2}$ catalyst exhibited an excellent stability for ethanol dehydrogenation into acetaldehyde and hydrogen. A long-term run at $673 \mathrm{~K}$ and $\mathrm{W} / \mathrm{Q}=33.3 \times 10^{-6} \mathrm{~g}_{\text {cat }} \mathrm{h} \mathrm{mL}^{-1}$ 
was conducted for $80 \mathrm{~h}$ and no deactivation in terms of ethanol transformation was observed.

\subsection{Acetaldehyde reforming over $\mathrm{Co}(\mathrm{Fe}) / \mathrm{ZnO}$}

The $\mathrm{Co}(\mathrm{Fe}) / \mathrm{ZnO}$ catalyst contained well-dispersed, bimetallic $\mathrm{Co}-\mathrm{Fe}$ nanoparticles over $\mathrm{ZnO}$ crystallites of about $40 \mathrm{~nm}$. The BET surface area was $45 \mathrm{~m}^{2} \mathrm{~g}^{-1}$. The bimetallic nature of particles was evidenced by XRD and HRTEM techniques. Figure $3 b$ shows the XRD pattern of the catalyst where, in addition to narrow signals due to $\mathrm{ZnO}$, a broad line at $44.8^{\circ}$ corresponds to a Co-Fe alloy (pure Co (111) line is located at $51.8^{\circ}$ ). Figure $4 \mathrm{~b}$ shows a representative HRTEM image of the catalyst with a well-faceted Co-Fe particle. Lattice fringes at $2.02 \AA$ correspond to the (111) plane of Co-Fe alloy. Energy electron loss spectra (EELS) recorded over single particles shows the presence of both $\mathrm{Co}$ and $\mathrm{Fe}$, in accordance to the bimetallic nature of particles. Surface composition is $\mathrm{Fe}_{\mathrm{at}} / \mathrm{Co}_{\mathrm{at}}=0.2$ and $\mathrm{Na}_{\mathrm{at}} / \mathrm{Co}_{\mathrm{at}}=1.0$ as deduced from X-ray photoelectron spectroscopy.

The acetaldehyde-steam mixture was transformed over the $\mathrm{Co}(\mathrm{Fe}) / \mathrm{ZnO}$ catalyst into a mixture of hydrogen, carbon monoxide, and carbon dioxide under the experimental conditions used in this work. The selectivity towards methane was always maintained below $0.3 \%$ on a carbon basis. The distribution of products depended on temperature and W/Q. In particular, the higher the W/Q and the temperature, the higher the yield of hydrogen and $\mathrm{CO}_{2}$. This is shown in Figure 7 for the results obtained at $673 \mathrm{~K}$. The effect of W/Q may be explained in terms of two consecutive reactions, namely the reforming of acetaldehyde into hydrogen and carbon monoxide (10), and the reaction of carbon monoxide with steam through the water gas shift reaction (3). 


$$
\mathrm{C}_{2} \mathrm{H}_{4} \mathrm{O}+\mathrm{H}_{2} \mathrm{O} \rightarrow 2 \mathrm{CO}+3 \mathrm{H}_{2}
$$

The product distribution obtained in the experiments is in all cases in good agreement with the stoichiometry of reactions (10) and (3), and the equation:

$$
C_{\mathrm{H}_{2}}=C_{\mathrm{CO}_{2}}+\frac{3}{2}\left(C_{C O}+C_{\mathrm{CO}_{2}}\right)
$$

at the reactor outlet holds true within the experimental error. The extent of the water gas shift reaction increases as W/Q increases due to a larger contact time between the reaction mixture and the catalyst. The increase of reaction temperature has also a positive effect on the water gas shift reaction in the temperature range used in this work. This is illustrated in Figure 8, where the molar ratio between $\mathrm{CO}_{2}$ and $\mathrm{CO}$ is plotted against W/Q at different temperatures. The maximum $\mathrm{H}_{2}$ yield and $\mathrm{CO}_{2} / \mathrm{CO}$ ratio is encountered at $673 \mathrm{~K}$ and $16.7 \times 10^{-6} \mathrm{~g}_{\text {cat }} \mathrm{h} \mathrm{mL}^{-1}$.

Concerning the kinetics of acetaldehyde steam reforming over the $\mathrm{Co}(\mathrm{Fe}) / \mathrm{ZnO}$ catalyst, Figure 9 shows a plot of the $\log$ of residual acetaldehyde vs. W/Q at different temperatures between 598 and $673 \mathrm{~K}$. It is found that the data at each temperature fall on a straight line. This, following equation (9), means that the reaction is first order with respect to acetaldehyde. The first-order dependence on acetaldehyde is in agreement with results reported for other catalysts that have been studied for the ethanol reforming reaction, taking into account that the first step of the reaction is the dehydrogenation of ethanol into acetaldehyde, and that this first step is also a first order reaction. These other catalysts that have shown first-order dependence with respect to ethanol are $\mathrm{Ru} / \mathrm{Al}_{2} \mathrm{O}_{3}$ [15], $\mathrm{Ni} / \mathrm{Al}_{2} \mathrm{O}_{3}, \mathrm{Ni} / \mathrm{La}_{2} \mathrm{O}_{3}$ and $\mathrm{Ni} / \mathrm{Y}_{2} \mathrm{O}_{3}$ [16], and Cu plated Raney $\mathrm{Ni}$ [17].

In all experiments performed over $\mathrm{Co}(\mathrm{Fe}) / \mathrm{ZnO}$ the steam-to-carbon ratio of $\mathrm{S} / \mathrm{C}=3$ is much higher than that required from stoichiometry (equation 10). The excess of water 
employed serves for preventing carbon deposition on the catalyst surface [4]. The slopes of the lines in Figure 9 yield the apparent reaction rate constants at each temperature, k' (equation 10). Table 2 compiles the values of $\mathrm{k}^{\prime}$ at the different temperatures tested along with their $95 \%$ confidence intervals. A pre-exponential factor of $1.3 \times 10^{12} \mathrm{~mL} \cdot \mathrm{g}_{\mathrm{cat}}{ }^{-}$ ${ }^{1} \cdot \mathrm{h}^{-1}$ is fitted from the data in Table 2. An Arrhenius plot of the apparent rate constants is shown in Figure 10. A good linearity is obtained, and from the slope value activation energy of $98 \pm 4 \mathrm{~kJ} \mathrm{~mol}^{-1}$ is obtained. Regarding the stability of the catalyst, it should be mentioned that a slow, but constant deactivation was observed during long-term runs at $673 \mathrm{~K}$ and $\mathrm{W} / \mathrm{Q}=16.7 \times 10^{-6} \mathrm{~g}_{\text {cat }} \mathrm{h} \mathrm{mL}^{-1}$ over the $\mathrm{Co}(\mathrm{Fe}) / \mathrm{ZnO}$ catalyst under acetaldehyde steam reforming. Acetaldehyde conversion decreased ca. 3\% after continuous operation for $140 \mathrm{~h}$, although no significant change of selectivity was observed.

\subsection{Water gas shift reaction over $\mathrm{Fe}_{2} \mathrm{O}_{3}-\mathrm{Cr}_{2} \mathrm{O}_{3}$}

From Figures 8 and 9 it is deduced that the conversion of $\mathrm{CO}$ into $\mathrm{CO}_{2}$ is not complete over the $\mathrm{Co}(\mathrm{Fe}) / \mathrm{ZnO}$ catalyst under the reaction conditions used in this work. To reduce the $\mathrm{CO}$ content of the stream leaving the reforming stage and to increase the hydrogen yield, a third stage is introduced, where the water gas shift reaction (WGSR, equation 3) is performed. To shift the thermodynamic equilibrium towards $\mathrm{H}_{2}$ and $\mathrm{CO}_{2}$, this stage is operated at a lower temperature than the preceding stages (ethanol dehydrogenation into acetaldehyde and acetaldehyde reforming). The water gas shift reaction (WGSR) is an industrially important reaction and several commercial catalysts are available as well as numerous studies of its reaction kinetics. For modeling purposes, the present 
contribution considers the kinetics of the WGSR over a $\mathrm{Fe}_{2} \mathrm{O}_{3}-\mathrm{Cr}_{2} \mathrm{O}_{3}$ catalyst as reported by Podolski and Kim [18].

\section{Dynamic modeling}

\subsection{Mathematical model}

To perform the intended ethanol reforming process three monolithic reactors in series are selected (see Figure 2). The reactors should provide the necessary hydrogen flow for the operation of a fuel-cell system for electric power generation. An accurate knowledge of the dynamic response of the reactors results essential towards the design of the control system of the whole unit, which should consider also the restrictions imposed by the fuel cell. The operation with chemical reactors usually implies difficulties in control issues due to the delays in response, the high sensibility to the operation temperature and the difficulty of obtaining intermediate measurements. Therefore, the development of a dynamic model of the reactor is an indispensable tool for the development of the controllers.

A one-dimensional, pseudo-homogeneous, non-steady-state model has been used to represent the ethanol reforming in the already referenced series of monolithic reactors. Pseudo-homogeneous mathematical models are usually selected for control-oriented applications to reduce the solving time of the equations system. Each of the first two monolithic sections is modeled with the catalysts data described in Section 3, the third unit is provided with a standard formulation for the water gas shift reaction [18]. For 
simplicity, no $\mathrm{CO}_{2}$ formation is considered in stage 2 of the model. Thermally-isolated lines are considered between sections. The use of low-diameter monoliths and optimized inlet distributors supports the assumption of 1-D model avoiding the occurrence of pronounced radial mass and temperature profiles. The outlet wall of the monolithic reactors are assumed at constant temperature (the reaction units are placed into a furnace), although different temperature levels are considered for the different stages. The pressure drop in the reactors was assumed negligible due to the high void fractions of monolithic structures $[19,20]$. The mass and energy balances used to represent the non-steady-state reactor behavior, along with the corresponding initial and boundary conditions, are presented below:

Mass balance (component j):

$$
\frac{\partial C_{j}}{\partial t}+\frac{\partial\left(v C_{j}\right)}{\partial z}=v_{j, i} r_{i}
$$

Energy balance:

$$
\left[\rho_{g} c_{p_{g}}+\rho_{s} c_{p_{s}}\right] \frac{\partial T}{\partial t}+\rho_{g} c_{p_{g}} v \frac{\partial T}{\partial z}=\frac{4 U}{d_{t}}\left(T_{F}-T\right)+\left(-\Delta H_{i}\right) r_{i}
$$

The numerical solution of the set of partial differential equations 12 and 13 was accomplished by its transformation into an ODE-system by discretization of the spatial derivative. To this end, backward finite differences have been selected (first-order, 90 discretization points for the reported simulations). The resultant ODE equations were solved by an algorithm implemented in MATLAB ${ }^{\mathrm{TM}}$ (ODE45 Normand-Prince). The ideal gas assumption is considered due to the low operating pressure of ca. 1 bar. Values of the specific heat for each component and of the gas mixture are taken from Perry 
[21]. A bulk void fraction of $\varepsilon=0.66$ is consequent with the modeled monolithic reactors. A catalyst loading of $0.15 \mathrm{~kg}_{\text {cat }} \mathrm{kg}_{\mathrm{s}}^{-1}$ and a total solid density of $\rho \mathrm{s}_{\mathrm{s}}=500 \mathrm{~kg}_{\mathrm{s}} \mathrm{m}^{-}$ ${ }_{\mathrm{R}}^{3}$ are considered for modeling purposes. The evaluation of the overall-heat-transfer coefficient (U) was performed by following the guidelines suggested in Calderbank and Pogorski [22].

\subsection{Simulations}

The stages of the proposed ethanol reforming system were dimensioned to provide the necessary hydrogen flow to feed a $1 \mathrm{~kW}$ fuel cell $\left(14 \mathrm{STP} \mathrm{L} \min ^{-1} \mathrm{H}_{2}\right)$. Conversions of ethanol and acetaldehyde of $95 \%$ are considered for the first two stages, while a CO conversion of $97 \%$ is required for the final WGS stage. Reactor volumes of 4.1, 4.4 and 0.45 liters result from these requirements for an input flow comprising $3.27 \mathrm{mmol} \mathrm{s}^{-1}$ of ethanol and $32 \mathrm{mmol} \mathrm{s}^{-1}$ of water and operating temperatures of 648,673 and $633 \mathrm{~K}$ for each stage, respectively. Assuming a maximum monolith diameter of $0.02 \mathrm{~m}$, a multitubular configuration for the different stages would be required to lead to a feasible design.

Steady-state axial concentration profiles are presented in Figures 11 to 13 for stages 1 to 3, respectively. This situation represents a base operating condition from where dynamic perturbations are performed, as described below. Heat flows of $+200 \mathrm{~W}$ and $+565 \mathrm{~W}$ are required for stages 1 and 2 , while stage 3 delivers $-242 \mathrm{~W}$, resulting in a heat requirement of $+523 \mathrm{~W}$ for the whole unit. This value represents ca. $13 \%$ of the LHV of the hydrogen provided by the system. 
In Figures 14-16, the concentration profiles at the exit of the three reactor zones are shown after disturbing the input flow, and assuming a volumetric flowrate constant. Specifically, at $\mathrm{t}=10 \mathrm{~s}$ a step is simulated in the concentration of ethanol $(+10 \%$ during $5 \mathrm{~s})$, and at $\mathrm{t}=50 \mathrm{~s}$ a step in the water concentration $(+10 \%$ during $5 \mathrm{~s})$ is simulated. Temperature disturbances (input flow temperature and furnace temperatures of the three stages) were also applied in the simulated system and a sensitivity analysis is currently being done. The pure delay of approximately 11 seconds observed in the dynamic response (Figures 14, 15 and 16), and the sensibility of the production of hydrogen to the input will be critical points for the design of controllers able of supplying fuel cells with changeable load.

\section{Conclusions}

A three-stage ethanol reformer has been ideated for operating at low temperature with a Co-based catalyst. The three stages correspond to ethanol dehydrogenation over $\mathrm{SnO}_{2}$, acetaldehyde reforming over $\mathrm{Co}(\mathrm{Fe}) / \mathrm{ZnO}$, and water gas shift reaction over commercial $\mathrm{Fe}_{2} \mathrm{O}_{3}-\mathrm{Cr}_{2} \mathrm{O}_{3}$. Kinetic parameters have been obtained in various sets of experiments, which have been used for the design of a tubular reactor loaded with catalytic monoliths for real application. A mathematical dynamic model has been developed and used to simulate the dynamic response (sensibility and response delay) of the reformer in the production of hydrogen following changes in the input variables. These characteristics will have important implications for the integration of the reformer with a fuel cell of changeable load.

\section{Acknowledgements}


This research was supported by projects MEC ENE2006-06925 and CICYT DPI2007626966.

\section{Nomenclature}

$\mathrm{C}=$ concentration, $\mathrm{mol} / \mathrm{m}^{3}{ }_{\mathrm{R}}$

$\mathrm{c}_{\mathrm{p}}=$ specific heat, $\mathrm{J} /(\mathrm{Kg} \mathrm{K})$

$\mathrm{d}_{\mathrm{t}}=$ monolith external diameter, $\mathrm{m}$

$\mathrm{k}=$ reaction rate constant, $\mathrm{STAGE} 1, \mathrm{~mL} /\left(\mathrm{g}_{\text {cat }} \mathrm{h}\right)$

$\mathrm{k}^{\prime}=$ reaction rate constant, STAGE $2, \mathrm{~mL} /\left(\mathrm{g}_{\text {cat }} \mathrm{h}\right)$

$\mathrm{Q}=$ volumetric flowrate at reactor inlet, $\mathrm{mL} / \mathrm{min}$

$\mathrm{r}=$ reaction rate, $\mathrm{mol} /\left(\mathrm{m}_{\mathrm{R}}^{3} \mathrm{~s}\right)$

$\mathrm{t}=$ time, $\mathrm{s}$

$\mathrm{T}$ = temperature, $\mathrm{K}$

$\mathrm{T}_{\mathrm{F}}=$ furnace temperature, $\mathrm{K}$

$\mathrm{v}=$ superficial velocity, $\mathrm{m} / \mathrm{s}$

$\mathrm{U}=$ overall heat-transfer coefficient, $\mathrm{J} /\left(\mathrm{s} \mathrm{m}^{2} \mathrm{~K}\right)$

$\mathrm{W}=$ catalyst mass, $\mathrm{g}$

$\mathrm{x}=$ conversion

$\mathrm{y}=$ molar fraction

$\mathrm{z}=$ axial coordinate, $\mathrm{m}$

Subindex 
cat $=$ catalyst

$\mathrm{g}=$ gas

$\mathrm{i}=$ reaction number, $\mathrm{i}=1 \ldots 3$ (eq. 6,10 and 3 , respectively)

in $=$ at reactor inlet

$\mathrm{j}=$ component number, $\mathrm{j}=1 \ldots 6\left(\mathrm{C}_{2} \mathrm{H}_{5} \mathrm{OH}, \mathrm{H}_{2} \mathrm{O}, \mathrm{C}_{2} \mathrm{H}_{4} \mathrm{O}, \mathrm{H}_{2}, \mathrm{CO}, \mathrm{CO}_{2}\right.$, respectively $)$

out $=$ at reactor outlet

$\mathrm{R}=$ reactor

$\mathrm{s}=$ solid

Greek letters

$\Delta \mathrm{H}^{\mathrm{o}}{ }_{298}=$ heat of reaction, $\mathrm{J} / \mathrm{mol}$

$\varepsilon=$ bed void fraction, $\left(1-\mathrm{m}_{\mathrm{s}}^{3}\right) / \mathrm{m}_{\mathrm{R}}^{3}$

$v_{j i}=$ stoichiometric coefficient of component $j$ in reaction $i$

$\rho=$ density, $\mathrm{kg} / \mathrm{m}^{3}$

\section{References}

[1] P.D. Vaidya, A.E. Rodrigues. Chem. Eng. J. 2006, 117, 39-49.

[2] A. Haryanto, S. Fernando, N. Murali, S. Adhikari. Energy Fuels 2005, 19, 20982106.

[3] Llorca, J., Homs, N., Sales, J. and Ramírez de la Piscina, P. J. Catal. 2002, 209, $306-317$. 
[4] Llorca, J., Ramírez de la Piscina, P., Dalmon, J.A., Sales, J. and Homs, N. Appl. Catal. B:Environ. 2003, 43, 355-369.

[5] Casanovas, A., Saint-Gerons, M., Griffon, F., Llorca, J. Int. J. Hydrogen Energy, 2008, 33, 1827-1833.

[6] Llorca, J., Casanovas, A., Trifonov, T., Rodríguez, A., Alcubilla, R. J. Catal. 2008, 255, 228-233.

[7] Torres, J.A., Llorca, J., Casanovas, A., Domínguez, M., Salvadó, J., Montané, D. J. Power Sources, 2007, 169, 158-166.

[8] S. Cavallaro, N. Mondello, S. Freni. J. Power Sources 2001, 198-204.

[9] Llorca, J., Ramírez de la Piscina, P., Sales, J. and Homs, N. Chem. Commun. 2001, 641-642.

[10] S.C. Lyu, T.J. Lee, C.W. Yang, C.J. Lee. Chem. Commun. 2003, 1404-1405.

[11] Llorca, J., Homs, N., Sales, J., Fierro, J.L.G. and Ramírez de la Piscina, P. J. Catal. 2004, 222, 470-480.

[12] Llorca, J., Homs, N., Ramírez de la Piscina, P. J. Catal. 2004, 227, 556-560.

[13] Llorca, J., Dalmon, J.A., Ramírez de la Piscina, P. and Homs, N. Appl. Catal. A:Gen. 2003, 243, 261-269.

[14] Llorca, J., Ramírez de la Piscina, P., Dalmon and Homs, N. Chem. Mater. 2004, $16,3573-3578$.

[15] P.D. Vaidya, A.E. Rodrigues. Ind. Eng. Chem. Res. 2006, 45, 6614-6618.

[16] J. Sun, X.-P. Qiu, F. Wu, W.-T. Zhu. Int. J. Hydrogen Energy 2005, 30, 437445.

[17] D.A. Morgenstern, J.P. Fornango. Energy Fuels 2005, 19, 1708-1716.

[18] W.F. Podolski, Y.G. Kim. Ind. Eng. Chem. 1974, 13, 415. 
[19] S. Irandoust, B. Andersson, "Monolithic Catalysts for Nonautomobile Applications”, Catal. Rev. Sci. Eng. 1988, 30 (3), 343-391.

[20] A. Cybulski, J.A. Moulijn, "Monoliths in Heterogeneous Catalysis", Catal. Rev. Sci. Eng. 1994, 36 (2), 179-269.

[21] R.H. Perry, C.H. Chilton, "Manual del Ingeniero Químico", McGraw-Hill, Bogotá, 1982.

[22] P.H. Calderbank, L.A. Pogorski, "Heat transfer in packed beds", Trans. Inst. Chem. Eng. 1957, 35, 195. 
Figure 1. Scheme of steam reforming of ethanol over cobalt-based catalysts.

Figure 2. Schematic representation of the three stage reforming process

Figure 3. X-ray diffraction profiles of catalysts $\mathrm{SnO}_{2}(\mathrm{a})$ and $\mathrm{Co}(\mathrm{Fe}) / \mathrm{ZnO}(\mathrm{b})$.

Figure 4. High resolution transmission electron microscopy images of catalysts $\mathrm{SnO}_{2}$ (a) and $\mathrm{Co}(\mathrm{Fe}) / \mathrm{ZnO}(\mathrm{b})$.

Figure 5. Semilog plot of the mole fraction of unreacted ethanol as a function of W/Q at various temperatures over catalyst $\mathrm{SnO}_{2}$.

Figure 6. Semilog plot of the specific reaction rates constants for the dehydrogenation of ethanol over catalyst $\mathrm{SnO}_{2}$.

Figure 7. Product distribution on a molar basis of carbon-containing products obtained in the acetaldehyde steam reforming reaction over catalyst $\mathrm{Co}(\mathrm{Fe}) / \mathrm{ZnO}$ at $673 \mathrm{~K}$ at different $\mathrm{W} / \mathrm{Q}$ values.

Figure 8. Molar ratio between $\mathrm{CO}$ and $\mathrm{CO}_{2}$ at different $\mathrm{W} / \mathrm{Q}$ values and temperatures obtained after steam reforming of acetaldehyde over catalyst $\mathrm{Co}(\mathrm{Fe}) / \mathrm{ZnO}$.

Figure 9. Semilog plot of the mole fraction of unreacted acetaldehyde as a function of $\mathrm{W} / \mathrm{Q}$ at various temperatures over catalyst $\mathrm{Co}(\mathrm{Fe}) / \mathrm{ZnO}$. 
Figure 10. Semilog plot of the specific reaction rates constants for the steam reforming of acetaldehyde over catalyst $\mathrm{Co}(\mathrm{Fe}) / \mathrm{ZnO}$.

Figure 11. Stage 1, Axial concentrations profiles at $648 \mathrm{~K}$

Figure 12. Stage 2, Axial concentrations profiles at $673 \mathrm{~K}$

Figure 13. Stage 3, Axial concentrations profiles at $633 \mathrm{~K}$

Figure 14. Stage 1: Exit concentrations ( $\mathrm{z}=\mathrm{L})$ Perturbations: Step of Ethanol of $10 \%$ between 10 and $15 \mathrm{~s}$ and Step of Water of $10 \%$ between 50 and $55 \mathrm{~s}$

Figure 15. Stage 1: Exit concentrations ( $\mathrm{z}=\mathrm{L})$ Perturbations: Step of Ethanol of $10 \%$ between 10 and $15 \mathrm{~s}$ and Step of Water of $10 \%$ between 50 and $55 \mathrm{~s}$

Figure 16. Stage 3: Exit concentrations ( $\mathrm{z}=\mathrm{L}$ ) Perturbations: Step of Ethanol of $10 \%$ between 10 and $15 \mathrm{~s}$ and Step of Water of $10 \%$ between 50 and $55 \mathrm{~s}$ 